Aneta Bąk

(Kielce)

\title{
Muzeum Zabawek i Zabawy - Kielce
}

Muzeum Zabawek i Zabawy (dawne Zabawkarstwa) powstało w 1979 roku. Inicjatorami jego utworzenia byli uczestnicy Społecznego Komitetu Obchodów Międzynarodowego Roku Dziecka przy Krajowym Związku Spółdzielni Zabawkarskich w Kielcach. Ówczesny Krajowy Związek Spółdzielni Zabawkarskich zrzeszał i koordynował działalność ponad $80 \%$ producentów zabawek w Polsce. Stąd zrodziła się idea, aby stworzyć instytucję będącą zapleczem handlowym, badawczo-rozwojowym, naukowym wspomagającym produkcję zabawek. Według wstępnych założeń, Muzeum Zabawkarstwa miało spełniać w tym procesie ważną rolę: popularyzatora wiedzy o zabawkach i zabawkarstwie, jednostki oddziałującej na producentów zabawek. Miało być dla nich, a także projektantów instytucją doradczą w rozwijaniu nowych kierunków i kryteriów oceny użyteczności zabawek, które w sposób prawidłowy stymulowałyby fizyczny i intelektualny rozwój dziecka. Zarząd byłego Krajowego Związku Spółdzielni Zabawkarskich uchwałą z dnia 20 sierpnia 1979 r. powołał utworzenie Muzeum, określił także zakres jego prac i ustanowił Komitet Organizacyjny. Datę otwarcia Muzeum ustalono na dzień 1 grudnia 1979 r. Przewodniczącym Honorowego Komitetu Założycielskiego Muzeum Zabawkarstwa w Kielcach został ówczesny Minister Kultury i Sztuki - Zygmunt Najdowski. Jednocześnie Uchwałą Zarządu KZSZ z dnia 30 listopada 1979 roku - Muzeum Zabawkarstwa został nadany statut.

Otwarcie placówki nastąpiło w dniu 1 grudnia 1979 roku. Inaugurowała je Krajowa Wystawa Polskiej Zabawki. Ponieważ Muzeum nie dysponowało wówczas własnym lokalem, wystawę zorganizowano w salach ekspozycyjnych Muzeum Narodowego w Kielcach, tam też dokonano uroczystego otwarcia Muzeum Zabawkarstwa.

W latach 1979-1984 instytucja wchodziła w skład wewnętrznej struktury KZSZ. Od roku 1984 została wyodrębniona jako zakład własny związku, a od 1989 jako zakład własny Centrum Naukowo-Produkcyjnego Przemysłu Zabawkarskiego Spółdzielni Osób Prawnych w Kielcach. Na wniosek Rady Nadzorczej i Zarządu w/w centrum, z dniem 1 stycznia 1990 r. Muzeum Zabawkarstwa zostało przejęte przez Urząd Miasta Kielce. Prezydent Miasta, zarządzeniem z dnia 2 stycznia, nadał Muzeum nowy statut. Kolejny statut instytucji nadano Zarządzeniem Wojewody Kieleckiego z dnia 28 lutego 1991 r. Muzeum zostało także wpisane do prowadzonego przez Urząd Wojewódzki, rejestru instytucji kultury. Ostatecznie, po kolejnych zmianach Muzeum uzyskało, obowiązujący do 
chwili obecnej, nowy wpis do RIK, oraz nowy statut. Muzeum posiada status samorządowej instytucji kultury, finansowanej z budżetu gminy Kielce.

Kilka ważnych dat w historii Muzeum: od 1979 roku Muzeum gościnnie prezentuje swe zbiory w Muzeum Narodowym przy placu Partyzantów, wykorzystując jedną salę ekspozycyjną. Od 1 czerwca 1982 r. nową siedzibą dla zabawek staje się zabytkowy spichlerz przy ul. Zamkowej, taka sytuacja trwa do grudnia $1985 \mathrm{r}$. Wtedy to ekspozycja stała przy ulicy Zamkowej zostaje zamknięta, gdyż pomieszczenia nie spełniają podstawowych kryteriów użytkowania przewidzianych dla obiektów muzealnych. Na dłużej Muzeum zagościło w salach budynku biurowego Spółdzielczości Pracy przy ulicy Kościuszki, gdzie 1 czerwca 1988 r. otwiera stałą ekspozycję w trzech jego salach. Powierzchnia wystawiennicza wynosi 220 metrów kwadratowych, co powoduje, że tylko kilka procent zabawek udostępniono zwiedzającym. Muzeum funkcjonowało „w biurowcu”, istniało więc wiele powodów ograniczających jego atrakcyjność. Zbyt mała powierzchnia, brak środków na funkcjonowanie, ciągłe braki kadrowe. Latami władze miasta nie radziły sobie ze znalezieniem właściwego lokum dla tej instytucji. Propozycje były przeróżne (budynki szkół, pustostany do remontu). Mimo wszelkich przeciwności, Muzeum stale prowadziło swoją statutową działalność, realizowało działalność wystawienniczą, opracowywano eksponaty będące własnością Muzeum, nabywano nowe. Muzeum nawiązało wiele nowych kontaktów $\mathrm{z}$ placówkami o podobnym charakterze $\mathrm{w}$ kraju i za granicą (Niemcy, Węgry,Czechy, Słowacja, Portugalia). Reasumując, były to lata bardzo trudne, ale cały czas rozwijające Muzeum.

Rok 2006 był rokiem przełomowym dla placówki. Po dwudziestu latach oczekiwań, wielu latach funkcjonowania $\mathrm{w}$ budynku, dzielonym z kilkunastoma innymi instytucjami, Muzeum otrzymało samodzielną siedzibę. Jest nią nowo wyremontowany XIX-wieczny budynek dawnych hal targowych, usytuowany w centrum miasta. Siedziba posiada wspaniałe zaplecze do pracy muzealno-oświatowej. Dzięki niemu możliwe jest przygotowywanie i organizowanie wystaw na wysokim poziomie, szeroko pojęta działalność oświatowa oraz działalność naukowa. W roku 2006 Muzeum Zabawkarstwa zmieniło także nazwę na „Muzeum Zabawek i Zabawy”. „Nowe” Muzeum posiada 635 metrów powierzchni wystawienniczej. Jednocześnie prezentowanych na niej jest od 10 do 12 wystaw zarówno stałych, jak i czasowych. Pracownicy Muzeum dokładają wszelkich starań, by zwiedzanie wystaw było atrakcyjne, ciekawe, niezwykłe, proponowane są wystawy interaktywne, które nie tylko się ogląda, ale w określonych miejscach można częścią eksponatów się pobawić, dotknąć je.

Ze względu na specyfikę zbiorów Muzeum jest placówką nietypową. Zbiory usystematyzowane są w trzech działach: 1) zabawki współczesnej - obejmuje wyroby nieistniejących juź w większości polskich spółdzielni zabawkarskich, zakładów produkcyjnych przemysłu terenowego, rzemieślników, firm polskich i zagranicznych; 2) zbiór zabawek historycznych - zawiera eksponaty najcenniejsze m.in. XVIII i XIX-wieczne (najstarszy eksponat XVIII-wieczna lalka woskowa); 3) najmłodszy zbiór obejmuje zabawki etnograficzne - ludowe, ze wszystkich ośrodków zabawkarstwa ludowego w Polsce, poszerzony o eksponaty czeskie, węgierskie, słowackie, ukraińskie, rosyjskie. Poza wymienionymi zbiorami kielecka placówka posiada także doskonałe kolekcje. Wymienić tu należy unikatową na skalę europejską (ok. czterotysięczną) kolekcję żab, przekazaną dla Muzeum 
przez państwa Ewę i Stanisława Rusieckich z Londynu; kolekcję kilkuset szopek, przywiezionych z najbardziej egzotycznych miejsc na Ziemi, przekazaną dla Muzeum przez Martina i Teresę Bickel ze Szwajcarii; kolekcje: lalek, samochodów, zabawek ludowych. Wreszcie także wspaniałe kolekcje modelarskie: żaglowców Rafała Polaka, czy mikromodeli szkutniczych sześciokrotnego mistrza świata w modelarstwie okrętowym Władysława Herbusia. Od roku 1991 działa przy Muzeum pracownia modelarska. Jej głównym zadaniem jest podstawowe szkolenie modelarskie dzieci w wieku 9-15 lat. Młodzi modelarze wykonują głównie redukcyjne modele plastykowe i kartonowe oraz dioramy modelarskie. Od marca 2007 w Muzeum Zabawek i Zabawy działa sekcja modeli zdalnie sterowanych, a także sekcja modeli RC. Stałym elementem towarzyszącym wystawom, pokazom są prezentacje multimedialne. Kolejną atrakcją oferowaną przez kielecką placówkę jest „wylatująca” codziennie w południe z zegarowej wieży, usytuowanej na budynku Muzeum, świętokrzyska Baba Jaga.

Podczas zwiedzania dzieci mają okazję pobawić się w przygotowanym specjalnie dla nich kąciku zabaw, pelnym kolorowych klocków, lalek i samochodów. Chętnie zbieramy opinie o naszej placówce, rozmawiamy ze zwiedzającymi i zawsze wychodzimy naprzeciw ich oczekiwaniom. Dodam jeszcze, że budynek Muzeum Zabawek i Zabawy, jako jedyna instytucja kultury w Kielcach, nie posiada barier architektonicznych dla osób niepełnosprawnych. Umożliwia to stałą i owocną współpracę z placówkami o takim charakterze oraz osobami indywidualnymi. Placówka przechodzi metamorfozę. Dzięki nowej siedzibie poszerzyła znacznie zakres swojej działalności. Staje się nowoczesnym, multimedialnym ośrodkiem o zasięgu krajowym, w przyszłości europejskim. Muzeum pełni szerokie funkcje społeczne, muzealnicze, kulturotwórcze, dydaktyczne i naukowe, Wspótpracuje $\mathrm{z}$ wieloma instytucjami w kraju i za granicą. Zdecydowanie się rozwija i oferuje znacznie więcej ciekawych kulturalnych propozycji dla dzieci, młodzieży i dorosłych niż w latach ubiegłych. W ofercie „Muzeum są lekcje muzealne, warsztaty plastyczne, przeglądy filmowe. Wielkim sukcesem Muzeum jest pomysł i realizacja największej corocznej muzealnej imprezy. Od roku 1995 Muzeum nieprzerwanie organizuje (początkowo Festiwal Zabawkarski) obecnie Festiwal Zabaw Zabawek i Widowisk, w roku 2007 odbyła się jego 11 edycja. Niezmiennie jest to wielkie wydarzenie dla Muzeum i Miasta.

Wspominając o specyfice kieleckiego Muzeum zaznaczyć należy, że oprócz działalności wystawienniczej, oświatowej prowadzi działalność naukowo-badawczą. Od początku swego istnienia wspótpracuje z kilkoma placówkami naukowymi w kraju. Obecnie są to: Uniwersytet Śląski z fillią w Opolu i Cieszynie, Akademia Pedagogiczna w Krakowie, Uniwersytet Adama Mickiewicza w Poznaniu, Akademia Świętokrzyska. Muzeum organizuje i uczestniczy w seminariach i konferencjach naukowych dotyczących zabawek i zabawy i dyscyplin pokrewnych temu zagadnieniu. $W$ roku bieżącym, po dłuższej przerwie, wznowione zostały badania mające pomóc $\mathrm{w}$ stworzeniu atlasu zabawkarstwa ludowego oraz pomagające ochronie od zapomnienia zanikającego zawodu zabawkarza ludowego. Patronat, nad pracą naukową Muzeum sprawuje Rada Muzeum, powołana w 2006 r., w skład której wchodzą pracownicy naukowi wymienionych placówek

Muzeum cały czas rozwija się, realizuje cele wynikające $\mathrm{z}$ ustawy o muzeach, a także cele statutowe. Należy jednak zwrócić baczną uwagę i dołożyć wszelkich starań, aby zo- 
stały zachowane właściwe proporcje między działalnością muzealną a oświatową placówki. Bardzo ważny jest także stosunek do Muzeum lokalnych władz. To od ich przychylności, w znacznej mierze, zależy przyszłość i zaplecze finansowe Muzeum. Oto co powiedział o Muzeum Prezydent Kielc - Wojciech Lubawski w dniu otwarcia nowej siedziby:

„Muzeum Zabawek i Zabawy ...zajmuje znaczące miejsce na mapie kieleckich i polskich placówek kulturalnych. Bogate zbiory oraz różnorodna działalność naukowo-badawcza i oświatowa tej instytucji dają szerokie moźliwości naprawdę ciekawego spędzenia czasu...To szczególne miejsce, gdzie dorośli mają okazję odbyć podróż sentymentalną do lat dzieciństwa, a najmłodsi zobaczyć zabawki, które towarzyszyły ich rodzicom czy dziadkom".

\section{Wskazówki bibliograficzne:}

Bąk A., Modelarstwo zabawa nie tylko dla dzieci, [katalog wystawy], Kielce 2007

Muzeum Zabawek $i$ Zabawy w Kielcach [online], Kielce, Muzeum Zabawek i Zabawy [dostęp 11 grudnia 2007]. Dostępny w Word Wide Web: // www.muzeumzabawek.eu Muzeum Zabawek $i$ Zabawy, [folder], Kielce 2006.

Muzeum Zabawkarstwa w Kielcach, Zarys dziejów i organizacji oraz przebieg działalności w latach 1979-2000, Kielce 2000. Oprac. wewnętrzne.

Zięzio R., Muzeum Zabawkarstwa w Kielcach. Zarys dziejów i organizacji, charakterystyka działalności, „Zabawy i Zabawki” R. 1, nr 1-2 (1997), s. 131-139.

Aneta Bąk

\section{The Museum of Toys and Play - Kielce}

The article presents a short history of the Museum of Toys and Play in Kielce since its establishment in 1979 until present times.

Moreover, attempts have been taken to demonstrate how functioning of this institution changed over the years.

It has been shown that - apart from the fundamental activity concerning: the acquisition, description and presentation of the exhibits - the Museum fulfils a number of other functions.

Information has been revealed regarding the unique character and originality of the museum collections.

The questions of collectorship, co-operation with Polish and foreign museums and scholarly institutions in Poland have been dealt with.

A new image of the Museum of Toys and Play, which was created after moving the institution to the new building was noticed, as well as its development and a multi-faceted character. Also, it wasn't left unnoticed that the museum occupies now an important place on the map of Kielce. 